\title{
Вплив застосування препарату «Глутаргін» на перебіг відновних процесів у кваліфі- кованих спортсменів, що спеціалізуються з академічного веслування
}

\author{
А. М. Іванова
}

Державний науково-дослідний інститут фізичної культури і спорту, Київ, Україна

\begin{abstract}
Резюме. Изучена эффективность курсового применения препарата «Глутаргин» в соревновательном периоде годичного цикла подготовки спортсменов, специализирующихся в академической гребле. Полученные данные свидетельствуют о том, что курсовое применение препарата «Глутаргин» позитивно влияет на процессы восстановления в организме спортсменов и может быть рекомендовано для использования в процессе подготовки спортсменов высокого класса с целью повышения эффективности тренировочной и соревновательной деятельности.
\end{abstract}

Ключові слова: процессы восстановления, спортсмены-гребцы, физические нагрузки.

\begin{abstract}
Summury. The aim of the study was to investigate «Glutargin» efficiency in competition period in rowers. "Glutargin» intake has positive effect on recovery processes in the body of athletes and can be recommended for use in the preparation of high-class elite athletes to improve training and competitive activities.

Key words: recovery processes, rowers, physical exercises.
\end{abstract}

Постановка проблеми. Вибір способів корекції білкового обміну як за допомогою продуктів спеціального призначення для спортсменів, так і фармакологічних засобів з метою підвищення фрізичної працездатності та прискорення відновних процесів повинен базуватися на особливостях реакцій організму на специфрічні тренувальні та змагальні навантаження в певному виді спорту. Так, в академічному веслуванні під час проходження змагальної дистанції, що характеризується циклічною роботою субмаксимальної потужності, основними причинами втоми $\epsilon$ пригнічення діяльності нервових центрів і зміни внутрішнього середовища організму. Це зумовлено значною недостатністю кисню, внаслідок якої розвивається гіпоксемія, знижується рН крові, збільшується вміст молочної кислоти в крові. Кисневий борг досягає максимальних величин. Недоокиснені продукти обміну речовин, всмоктуючись у кров, пригнічують діяльність нервових клітин. Напружена діяльність нервових центрів, яка відбувається на фоні кисневої недостатності, призводить до швидкого розвитку втоми [5].

Відомо, що однією з особливостей метаболічних процесів, які виникають під час напруженої м'язової діяльності, $\epsilon$ активація білкового обміну. Істотний внесок в енергетику м'язової діяльності, особливо тривалої, вносять амінокислоти продукти розпаду ендогенних білків. Їх кількість у тканинах під час виконання тривалої фрізичної роботи може збільшуватися в 20-25 разів. Ці амінокислоти окиснюються і поповнюють запаси АТФ або залучаються до процесу новоутворення глюкози і сприяють підтриманню ії рівня в крові, а також рівня глікогену в печінці і скелетних м'язах.

Процеси розпаду білків та окиснення амінокислот під час м'язової діяльності супроводжуються посиленим утворенням аміаку, що зв'язується в печінці в циклі синтезу сечовини та виводиться $з$ організму. Тобто фрізичні навантаження викликають збільшення вмісту сечовини в крові, а нормалізація її рівня в період відпочинку свідчить про відновлення процесів розпаду і синтезу білків у тканинах [2].

Аміак $\epsilon$ одним із найбільш нейротоксичних ендогенних агентів. За добу в організмі здорової людини утворюється 4 г аміаку, ще 18 мг надходить $з$ їжею та водою, менше 1 г - в процесі дихання. Більша частина ендогенного аміаку утворюється в печінці внаслідок окисного дезамінування амінокислот. Інші аміакпродукуючі реакції - дезамінування амідів амінокислот (глутаміну, аспарагіну), біогенних амінів (норадреналіну, дофраміну), пуринових і піримідинових основ - мають менш інтенсивний перебіг. У свою чергу печінка $\epsilon$ основним органом, що нейтралізує аміак. Знешкодження аміаку здійснюється за допомогою двох основних 


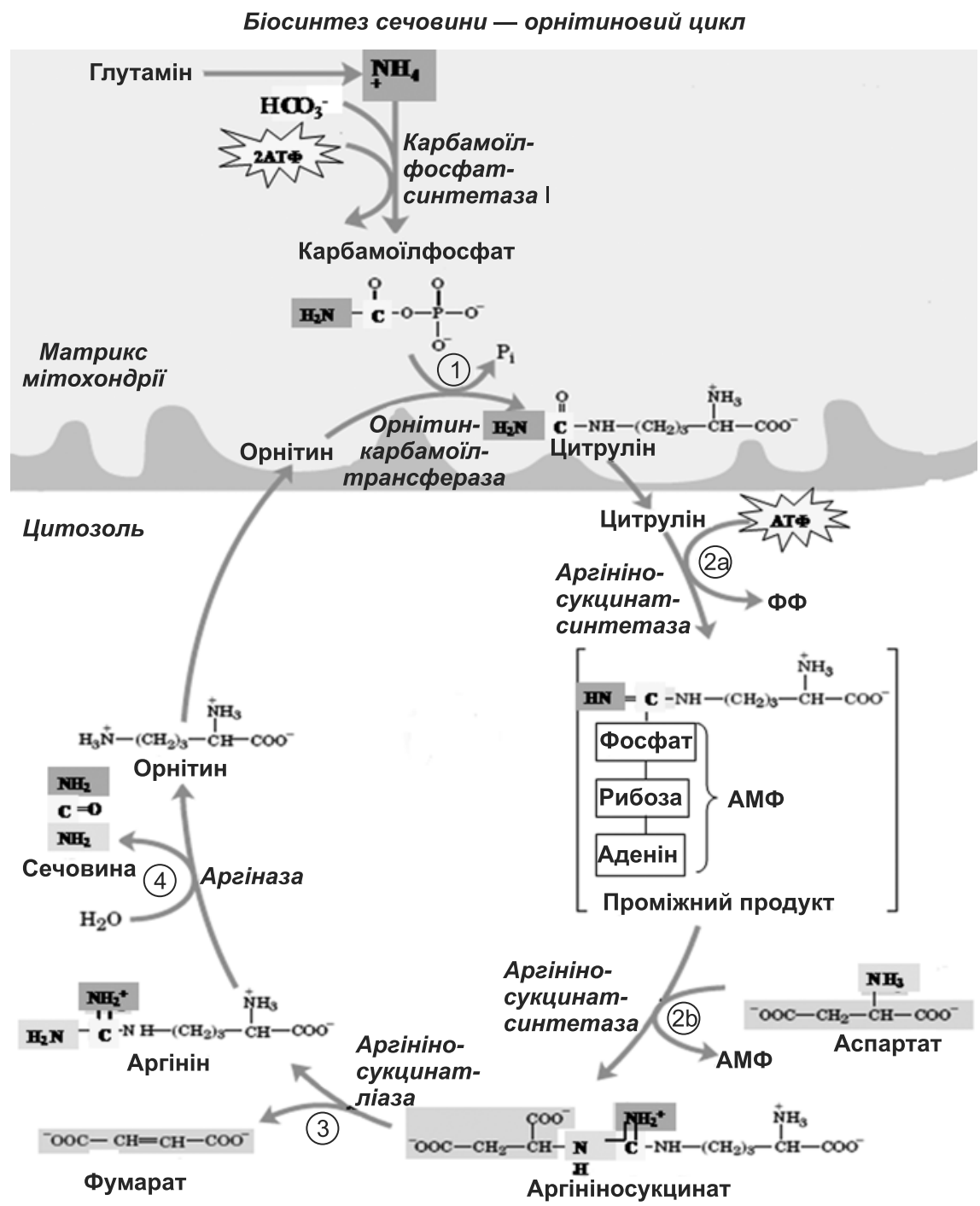

Рисунок 1 - Процес утворення сечовини в орнітиновому циклі клітин головного мозку, і як наслідок - до розвитку гіпоксії.

Основними завданнями змагального періоду $\epsilon$ збереження і наступне підвищення досягнутого рівня спеціальної підготовленості та, можливо, більш повне його використання в основних змаганнях, що досягається виконанням змагальних та близьких до них спеціально-підготовчих вправ. Виходячи 3 цього, одним із пріоритетних напрямів спортивної науки в цьому періоді річного циклу підготовки $\epsilon$ прискорення відновних процесів в організмі спортсменів 3 метою профілактики виникнення синдрому перетренованості, травм, передпатологічних та патологічних станів [4, 9].

Як засоби, що дають змогу уникнути цієї ситуації, використовують гепатопротектори, до яких традиційно відносять: рослинні препарати на основі поліфенольних сполук (силібор, карсил, дарсил, гепарсил, легалон, хофрітол, гепабене та ін.); препарати есенційних фросфоліпідів (есенціале $\mathrm{H}$ та ін.); синтетичні препарати (антраль); органопрепарати (вітогепар). Дія гепатопротекторів спрямована на нормалізацію механізмів - синтезу сечовини та утворення глутаміну $[1,2,7]$. Найбільш значущим процесом $\epsilon$ утворення сечовини в орнітиновому циклі (цикл Кребса-Хенселайта), що відбувається переважно в перипортальних гепатоцитах (рис. 1).

Підвищення рівня аміаку через низку реакцій призводить до енергетичного голодування

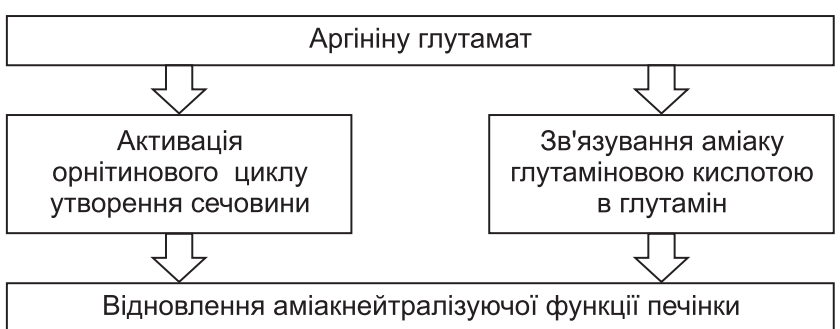

Рисунок 2 - Механізм аміакнейтралізуючої дії L-аргініну та глутамінової кислоти гомеостазу в печінці, підвищення стійкості органа до дії патогенних факторів, нормалізацію репаративно-регенеративних процесів $[1,6]$.

Слід зазначити, що як високоефективні та гіпоамоніємічні засоби перспективними $\epsilon$ препарати на основі амінокислот, зокрема аргініну та глутамінової кислоти. Висока гіпоамоніємічна активність цих амінокислот зумовлена їх регуляторними властивостями (активатори орерментів реакції знешкодження аміаку) та метаболічними (безпосередні учасники цих реакцій і субстрати (рис. 2).

Окрім вираженої гіпоамоніємічної дії ці амінокислоти виявляють низку властивостей, спрямованих на нормалізацію функції печінки (виражена антиоксидантна та антигіпоксична дії). Вони також стимулюють обмін речовин у печінці, нормалізують процеси енергозабезпечення в гепатоцитах [1]. 
На основі аргініну та глутамінової кислоти фармацевтичною компанією «Здоров я» спільно 3 Державним науковим центром лікарських засобів (м. Харків) було розроблено препарат «Глутаргін». За хімічною структурою - це сіль L-аргініну та глутамінової кислоти (рис. 3).

Препарат «Глутаргін» випускають у формі 4 та $40 \%$ розчину для ін'єкцій і таблеток.

Серед основних механізмів гепатопротекторної дії препарату «Глутаргін» слід відмітити його антитоксичні властивості, що реалізуються шляхом активації перетворення аміаку в сечовину в орнітиновому циклі сечовиноутворення. При цьому «Глутаргін» активує зв'язування аміаку глутаміновою кислотою, утворюючи глутамін [1].

Аналіз результатів, що були отримані в експерименті $[1,8]$ під час вивчення різних аспектів впливу препарату «Глутаргін» на гепатоцити, показав цілий ряд позитивних ефектів: покращення енергетичного обміну через первинне накопичення клітинної енергії у вигляді креатинооссрату; корекція кислотно-основного стану за рахунок нормалізації лужного запасу крові; антиоксидантна та мембраностабілізуюча дії через здатність знижувати рівень продуктів пероксидного окиснення ліпідів та підвищувати захисну функцію ендогенної антиоксидантної системи, а також стабілізувати мембрани гепатоцитів за рахунок зниження активності цитолітичних ферментів (аланін- та аспартатамінотрансоераз); антиішемічний ефрект через оптимізацію транспорту кисню та його споживання в тканинах та підвищення стійкості організму до гіпоксії. Крім того, незамінна амінокислота L-аргінін, яка разом з глутаміновою кислотою входить до хімічної структури гепатозахисного засобу «Глутаргін», $\epsilon$ безпосереднім попередником NO. Також в попередніх дослідженнях відмічено, що гепатопротекторна дія цього препарату, зумовлена стимулюючим впливом його складових на процеси детоксикації в печінці, посиленням пластичного й енергетичного обмінів у гепатоцитах, перевищує активність есенціале-Н $[1,3,8,10]$.

Механізм фрармакологічної дії препарату «Глутаргін» також зумовлений усуненням

$$
\begin{gathered}
{\left[\begin{array}{l}
\mathrm{H}_{2} \mathrm{~N}^{+}=\underset{\mathrm{NH}_{2}}{\mathrm{C}}-\mathrm{NH}-\mathrm{CH}_{2}-\mathrm{CH}_{2}-\underset{\mathrm{OOC}_{2}^{-}-\mathrm{CH}_{2}-\mathrm{NH}_{2}}{\mathrm{CH}}-\mathrm{COOH} \mathrm{H}_{2}-\mathrm{CH}-\mathrm{COH}
\end{array}\right]}
\end{gathered}
$$

Рисунок 3 - Хімічна структура препарату «Глутаргін» синдрому метаболічної інтоксикації, пов'язаного 3 накопиченням в організмі токсичних субстанцій - середніх молекул, а також низькомолекулярних токсичних сполук, серед яких, як було зазначено вище, найбільше значення надається аміаку. Глутаргін активує процеси зв'язування аміаку в циклі утворення сечовини і глутамінсинтетазної реакції; прискорює виведення аміаку завдяки стимуляції NO кровотоку як в центральній нервовій системі (посилення екскреції аміаку 3 нервових клітин), так і в нирках (елімінація аміаку з організму); знижує нейротоксичність аміаку за рахунок антигіпоксичного ефекту NO. Препарат «Глутаргін» сприяє відновленню білково-синтетичної фрункції печінки. Підвищення інтенсивності білкового синтезу відбувається в основному за рахунок глутамінової кислоти. Крім того, під впливом глутаргіну посилюється процес синтезу піримідинів і пуринів. Усунення порушень білково-синтетичної фрункції печінки є одним із механізмів нормалізації інших видів обміну, зокрема і ліпідного.

Як було зазначено вище, у процесі розпаду білків під час фрізичних навантажень утворюється підвищена кількість токсичного для організму аміаку, що, зв'язуючись у печінці, перетворюється на нетоксичну речовину - сечовину - та виводиться з організму. Беручи до уваги перелічені вище властивості препарату «Глутаргін», особливо гіпоамоніємічний ефект, який реалізується шляхом активації процесів знешкодження аміаку в орнітиновому циклі синтезу сечовини, зв'язування аміаку в нетоксичний глутамін, а також посилене виділення аміаку із центральної нервової системи та його екскреції з організму, ми дійшли висновку про доцільність використання цього препарату в практиці підготовки спортсменів.

Зв'язок із науковими програмами та практичними завданнями. Наукові дослідження виконано в рамках Зведеного плану НДР у сорері фрізичної культури і спорту на 2006-2010рр. за темою "Дослідження ефективності використання ергогенних чинників в системі підготовки спортсменів високого рівня», шифр теми 2.4.11. та на 2011-2015 рр. за темою «Контроль та корекція метаболізму при великих фрізичних навантаженнях різної спрямованості у кваліфрікованих спортсменів», шифр теми 2.28.

Мета дослідження - визначити ефективність курсового застосування препарату «Глутаргін» у змагальному періоді річного циклу підготовки спортсменів, що спеціалізуються 3 академічного веслування. 
Методи та організація дослідження. 3 метою встановлення ефективності застосування препарату «Глутаргін» в практиці підготовки кваліфрікованих спортсменів було обстежено спортсменів, що спеціалізуються 3 академічного веслування, членів збірної команди України (МСМК, ЗМС), яких було розподілено на дві споріднені групи по сім чоловік (експериментальну та контрольну). Відповідно до даних календарних диспансерних обстежень, усі іспитовані були практично здорові. Зазначений вище препарат спортсмени експериментальної групи (7 чоловік) вживали за такою схемою: по одній таблетці (0,75 г) 2 рази на добу після тренувань впродовж мікроциклу (один тиждень). Контрольна група спортсменів за аналогічною схемою вживала плацебо.

Для вивчення впливу курсового вживання препарату «Глутаргін» було використано такі загальноклінічні та біохімічні методи досліджень, а саме:

- визначення динаміки концентрації сечовини в крові (вранці натщесерце), що є інтегральним показником ступеня навантаженості м'язової системи і переносимості фрізичних навантажень;

- визначення концентрації гемоглобіну в крові (вранці натщесерце), що $€$ інфоормативним показником потенційних можливостей кисневотранспортної фуннкції крові, а також відображає ступінь перенесення фрізичних навантажень;

- визначення кількості еритроцитів у крові (формених елементів крові, що містять гемоглобін).

Концентрацію гемоглобіну, сечовини та кількість еритроцитів визначали в периферичній крові спортсменів на біохімічному аналізаторі LP-400 фрірми "Dr. Lange" (Німеччина) за допомогою стандартних наборів реактивів цієї самої фрірми.

Дослідження здійснювали в змагальний період річного циклу підготовки. Під час їх проведення тренувальний режим та навантаження експериментальної та контрольної груп не відрізнялися. Зазначені види тестування проводили на початку і наприкінці дослідження.

Отриманий цифровий матеріал обробляли методами статистики за допомогою програми «GraphPad Prism version 5.00 for Windows» (GraphPad software Inc., США).

Результати дослідження та їх обговорення. Аналіз результатів проведеного дослідження дає змогу констатувати, що курсове застосування препарату «Глутаргін» викликає позитивні зміни в системі крові спортсменів, що спеціалізуються 3 академічного веслування. Так, у спортсменів експериментальної групи спостерігалось прискорення відновних процесів в організмі під впливом курсового застосування препарату «Глутаргін», про що свідчило вірогідне зниження рівня сечовини у крові на 24,5 \% відносно вихідних даних ( $<<0,0001)$. На противагу цьому, у спортсменів контрольної групи також спостерігалось незначне зниження рівня сечовини крові, але лише на $6 \%$ відносно вихідних даних (р $<0,05)$. Беручи до уваги, що складові препарату «Глутаргін» виявляють гіпоамоніємічний ефект, який реалізується шляхом знешкодження аміаку в орнітиновому циклі синтезу сечовини, не викликає сумнівів фракт активації цих процесів під впливом курсового застосування досліджуваного препарату (рис. 4).

Що стосується впливу курсового застосування препарату «Глутаргін» на показники гемоглобіну та кількості еритроцитів, то, як видно 3 наведених у таблиці 1 даних, у спортсменів як експериментальної, так і контрольної груп вірогідних змін не спостерігалося.

Слід також відмітити, що, за суб'єктивними оцінками спортсменів експериментальної групи, їх самопочуття під час виконання тренувальних навантажень та під час відновлення організму у

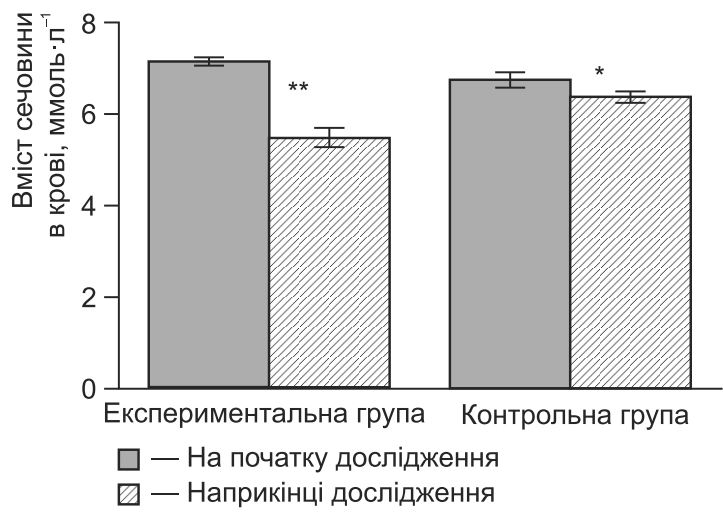

Рисунок 4 -Вплив курсового застосування препарату «Глутаргін» на вміст сечовини в крові спортсменів, що спеціалізуються з академічного веслування $(\mathrm{x} \pm \sigma ; \mathrm{n}=7$ у кожній групі)

Примітка. ${ }^{*} \mathrm{p}<0,05 ;{ }^{* \star} \mathrm{p}<0,0001$ відносно вихідних даних.

ТАБЛИЦЯ 1 - Вплив курсового вживання препарату

«Глутаргін» на показники крові спортсменів, що спеціалізуються 3 академічного веслування ( $\mathbf{x} \pm \sigma ; \mathbf{n}=\mathbf{7}$ у кожній групі)

\begin{tabular}{|c|c|c|c|c|}
\hline \multirow[b]{2}{*}{ Показник } & \multicolumn{2}{|c|}{ Експериментальна група } & \multicolumn{2}{|c|}{ Контрольна група } \\
\hline & $\begin{array}{c}\text { на початку } \\
\text { дослідження }\end{array}$ & $\begin{array}{c}\text { наприкінці } \\
\text { дослідження }\end{array}$ & \begin{tabular}{|c|} 
на початку \\
дослідження
\end{tabular} & $\begin{array}{l}\text { наприкінці } \\
\text { дослідження }\end{array}$ \\
\hline $\begin{array}{l}\text { Гемоглобін, } \\
\Gamma \cdot \Omega^{-1}\end{array}$ & $149,8 \pm 6,3$ & $149,8 \pm 9,7$ & $152,8 \pm 5,5$ & $153,7 \pm 4,8$ \\
\hline $\begin{array}{l}\text { Еритроцити, } \\
\cdot 10^{12} \Omega^{-1}\end{array}$ & $4,76 \pm 0,36$ & $4,88 \pm 0,34$ & $4,93 \pm 0,30$ & $4,9 \pm 0,18$ \\
\hline $\begin{array}{l}\text { Кольоровий } \\
\text { показник }\end{array}$ & $0,94 \pm 0,04$ & $0,92 \pm 0,03$ & $0,93 \pm 0,04$ & $0,94 \pm 0,03$ \\
\hline
\end{tabular}


цьому періоді річного циклу підготовки було кращим порівняно з періодом, коли вони не застосовували цей фрармацевтичний препарат.

\section{Висновки}

На підставі здійснених експериментальних досліджень встановлено, що курсове застосування препарату «Глутаргін» сприяє прискоренню

\section{Література}

1. Бабак О. Я. Применение нового отечественного препарата глутаргин в гастроэнтерологии / О. Я. Бабак // Сучасна гастроентерологія. - 2003. - № 2 (12). - С. 85-89.

2. Биохимия мышечной деятельности / [Н. И. Волков, Э. Н. Несен, А. А. Осипенко, С. Н. Корсун]. - К.: Олимп. лит., 2000. - 504 с.

3. Ванин $A$. Ф. L-аргинин - эндогенный источник оксида азота в тканях животных in vivo / А. Ф. Ванин, Л. Н. Кубрина, И. В. Маленкова, П. И. Мордвинцев // Біохімія. - 1991. - Т. 56. - Вып. 5. - С. 935-939.

4. Платонов В. Н. Система подготовки спортсменов в олимпийском спорте / В. Н. Платонов. - К.: Олимп. лит., 2004. -806 c.

5. СолодкоВ А. С. Физиология человека: общая, спортивная, возрастная: учеб. [для высш. учеб. заведений фриз. культуры] / А. С. Солодков, Е. Б. Сологуб. - М.: Олимпия Пресс, 2005. - 528 с.

6. Харченко Н. В. Порівняльна характеристика сучасних гепатопротекторів / Н. В. Харченко // Вісн. фармакології та фармації. - 2001. - № 3-4. - С. 18-26.

7. Чиркин $A$. $A$. Клинический анализ лабораторных данных / А. А. Чиркин. - М.: Мед. лит., 2010. - 384 с.

8. Чопорова O. I. Вплив глутаргіну на показники метаболічної інтоксикації у хворих на туберкульоз легень / О. І. Чопорова // Вісн. Харків. нац. ун-ту імені В. Н. Каразіна. - 2009. - Вип. 17, № 855. - С. 5663.

9. Уилмор Дж. Х. Физиология спорта / Дж. Х. Уилмор, Д. Л. Костилл. - К.: Олимп. лит., 2001. - 504 с.

10. Hon W. M. Nitric oxide and liver disesease: friend, foe, or just passerby? / W. M. Hon, K. N. Lee, H. E. Khoo, // Ann. N. Y. Acad. Sci. - 2002. - № 962. - P. 275-295. перебігу відновних процесів в організмі спортсменів після напружених фізичних навантажень в змагальному періоді річного циклу підготовки, про що свідчить вірогідне зниження рівня сечовини у крові на 24,5 \% порівняно з вихідними даними ( $p<0,0001)$ в експериментальній групі спортсменів.

\section{References}

1. Babak O. Y. Application of medicine "Glutarhyn" in gastroenterology / O. Y. Babak // Current Gastroenterology. - 2003. - N 2 (12). - P. 85-89.

2. Biochemistry of muscular activity / [N. I. Volkov, E. N. Nesen, A. A. Osipenko, S. N. Korsun]. - Kiev: Olympic literature, 2000. - $504 \mathrm{p}$.

3. Vanin A. F. L-arginine - endogenic resource of nitric oxide in the tissues of animals in vivo / A. F. Vanin, L. N. Kubryna, I. V. Malenkov, P. I. Mordvintseva / / Biochemistry. 1991. - T. 56. - Vol. 5. - P. 935-939.

4. Platonov V. N. The system of preparing athletes in Olympic sports / V. N. Platonov. - Kiev: Olympic literature, 2004. - 806 p.

5. Solodkov A. S. Human Physiology: general, sports, age. [guide for education.] / A. S. Solodkov, E. B. Sologub. Moscow: Olymp. lit., 2005. - 528 p.

6. Kharchenko N. V. Comparative characteristics of modern hepatoprotectors / N. V. Kharchenko // Journal of Pharmacology and Pharmacy. - 2001. - N 3-4. - P. 1826.

7. Chyrkyn A. A. Clinical analysis of laboratory data / A. A. Chyrkyn. - Moscow: Med. lit., 2010. - 384 p.

8. Choporova O. I. Effect "Glutargin" on parameters of metabolic intoxication in patients with pulmonary tuberculosis / O. I. Choporova / / Reporter of Kharkiv National University of V. N. Karazin. - 2009. - Vol. 17, N 855. - P. 56-63.

9. Wilmore J. H. Physiology of sport and exercise / J. H. Wilmore, D. L. Costill. - Kiev: Olympic literature, 2001. - 504 p.

10. Hon W. M. Nitric oxide and liver disesease: friend, foe, or just passerby? / W. M. Hon, K. N. Lee, H. E. Khoo, // Ann. N. Y. Acad. Sci. - 2002. - N 962. - P. 275-295. 